\title{
HYPERBARIC COLD STORAGE VERSUS CONVENTIONAL REFRIGERATION FOR EXTENDING THE SHELF-LIFE OF HAKE LOINS
}

Institute of Food Science, Technology and Nutrition (ICTAN-CSIC). c/ José Antonio Novais, 10, 28040 Madrid, Spain

\section{ABSTRACT}

Today, extending the shelf-life of fish, while retaining the organoleptic properties of the product, is still a challenge. To compare the effectiveness of conventional and hyperbaric cold storage in preserving fish quality, we stored Cape hake loins at $5{ }^{\circ} \mathrm{C}$, both at atmospheric pressure and at $50 \mathrm{MPa}$. After 7 days of storage, microbial counts and total volatile basic-nitrogen content in conventionally refrigerated samples exceeded the limits recommended for consumption. By contrast, hyperbaric cold storage maintained these parameters unaltered, although it produced drip losses close to $5 \%$ and increased the shear resistance and whiteness of the raw samples by $44 \%$ and $9 \%$, respectively. Nevertheless, after cooking, weight losses were less than half of those of the control loins and whiteness differences disappeared. Consequently, the sensorial analysis could only find moderate differences between the samples before and after hyperbaric storage. These results clearly prove that hyperbaric cold storage was more efficient than conventional refrigeration for the preservation of hake loins.

Keywords: hyperbaric storage; cold storage; fish preservation; quality; hake

\section{INTRODUCTION}

Fish is a very perishable product. Spoilage starts immediately after the caught and it is mainly produced by biochemical reactions and the activity of microorganisms (Ashie, Smith, \& Simpson, 1996). To maintain high quality and safety in fish, preservation techniques must be

\footnotetext{
${ }^{1}$ Corresponding author: Tel.: +34 9154923 00; fax: +34 915493627 .

E-mail address: I.otero@ictan.csic.es (L. Otero).
} 
applied continuously, from the point of harvest through storage, processing, and distribution, until the point of consumption.

Unfortunately, most preservation methods fail to simultaneously extend the shelf-life of marine products and keep their organoleptic properties intact. Thus, some traditional techniques, such as salting, smoking, or canning, among others, are able to prolong the shelf-life of fish considerably, but they produce substantial changes in the original characteristics of the product. Refrigeration is the method that better retains the sensorial properties of fish but, in return, it can only be used to store fish for a few days because biochemical and microbial reactions, even though slowed down, still occur at a significant rate (Rahman, 1999). For this reason, in the last years, many efforts have been made by the fish-processing industry to look for new preservation methods (Ashie et al., 1996; Sampels, 2015; Wilhelm, 1982).

Hyperbaric storage could be an innovative solution. It consists in storing food under relatively low pressure, usually lower than $200 \mathrm{MPa}$, for time periods of some days, weeks, or even months. The efficacy of hyperbaric storage in prolonging the shelf-life of food has been proved in several products, both at room and at low temperature, either above or below $0{ }^{\circ} \mathrm{C}$ (Fernandes et al., 2014). Hyperbaric storage at room temperature has been found to be more efficient than conventional refrigeration for the preservation of fruit juices (Pinto et al., 2016; Segovia-Bravo, Guignon, Bermejo-Prada, Sanz, \& Otero, 2012), raw bovine meat (Freitas et al., 2016), and ready-to-eat pre-cooked foods (Moreira et al., 2015b), among others. Depending on the level employed, pressure can not only inhibit microbial growth as refrigeration does but also produce some damage in the microorganisms, resulting in microbial inactivation (BermejoPrada, López-Caballero, \& Otero, 2016; Freitas et al., 2016). Thus, Ko and Hsu (2001) observed that hyperbaric storage $\left(50-300 \mathrm{MPa} / 25^{\circ} \mathrm{C}\right)$ not only inhibited microbial growth in tilapia fillets but, at pressures between 200 and $300 \mathrm{MPa}$, it also produced certain microbial inactivation. Lamentably, these authors proved that fish freshness, even though better retained under pressure, was gradually lost over time (1-12 h), especially at pressures below $200 \mathrm{MPa}$. Furthermore, they observed considerable protein denaturation at pressures beyond $100 \mathrm{MPa}$ (Hsu \& Ko, 2001; Ko, Jao, Hwang, \& Hsu, 2006; Ko \& Hsu, 2002; Ko, Jao, \& Hsu, 2003). This is a well-known effect of pressure in myosystems and, thus, many authors in the literature have shown that pressure beyond $100 \mathrm{MPa}$ can affect some quality properties of fish, such as texture, color, or water-holding capacity, among others (Chéret, Chapleau, Delbarre-Ladrat, Verrez-Bagnis, \& De Lamballerie, 2005; Chevalier, Le Bail, \& Ghoul, 2001; Ko et al., 2006; Ko \& Hsu, 2002; Matser, Stegeman, Kals, \& Bartels, 2000; Montero \& Gómez-Guillén, 2004). It follows from the above that hyperbaric storage alone is a strategy not enough powerful to effectively preserve the fish freshness. Therefore, if a significant extension of the shelf-life is aimed, pressure should be combined with some other hurdles to limit fish degradation.

Combining hyperbaric storage with low temperature seems to be particularly promising. Thus, Charm, Longmaid, and Carver (1977) stored cod and pollock, at pressures close to $25 \mathrm{MPa}$ and temperatures between $1{ }^{\circ} \mathrm{C}$ and $-3^{\circ} \mathrm{C}$, for periods of up to 36 days. They proved that, unlike in 
conventional refrigeration, total bacterial counts in cod fillets did not increase during storage under pressure. Moreover, the organoleptic studies on raw and cooked samples showed that hyperbaric storage retained fish freshness better than conventional refrigeration. Thus, dressed whole cod and pollock were acceptable for consumption after 12 and 21 days of storage at 24 $\mathrm{MPa}$ and $1{ }^{\circ} \mathrm{C}$, respectively. By contrast, they were considered unacceptable when stored at atmospheric pressure for the same period. Unfortunately, after these encouraging results, no more investigations on hyperbaric cold storage were performed in fish.

All the facts set out above suggest that hyperbaric cold storage, at pressures below $100 \mathrm{MPa}$, could be effective in both extending the shelf-life of fish and preserving the organoleptic properties of the product. Obviously, this novel technology would be more expensive than conventional refrigeration. Thus, the total cost of hyperbaric cold storage not only includes the costs of high-pressure equipment, maintenance, and energy but also the costs associated to refrigeration. Even though the energy cost for compression is almost negligible, the price of high-pressure equipment is high. Consequently, the amortization can increase the cost of hyperbaric storage substantially (Bermejo-Prada, Colmant, Otero, \& Guignon, 2017). Nevertheless, it is important to note that this barrier has not stopped the implantation of other high-pressure technologies in the food industry when real advantages over the conventional techniques have been identified.

Therefore, the main objective of this paper was to assess whether hyperbaric cold storage could offer any advantage over conventional refrigeration for fish preservation. To test this hypothesis, we stored hake loins at $5{ }^{\circ} \mathrm{C}$ for 7 days, both at atmospheric pressure (conventional refrigeration) and at $50 \mathrm{MPa}$ (hyperbaric cold storage). After storage, we compared the quality of the hake loins, both before and after cooking, by using microbial, chemical, and physical quality indicators. Moreover, we also evaluated the effect of hyperbaric storage on the sensorial quality of the product. To do so, we compared hake loins before and after 7 days of hyperbaric cold storage to check if storage under pressure caused an overall difference in the product.

The current study provides valuable new data for evaluating the effectivity of hyperbaric storage in extending the shelf-life of fish and, thus, it increases the knowledge on this innovative technology for food preservation.

\section{MATERIALS AND METHODS}

\subsection{Sample}

Three frozen batches of Cape hake loins (Merluccius spp.: M. capensis, Cast/ M. paradoxus, Franca), commercialized by three different Spanish manufacturers, were acquired in a local market and stored at $-20^{\circ} \mathrm{C}$ until utilization. According to the product label, hakes were captured at the Southeast Atlantic Ocean, cut in portions, packed, and frozen on board. Loin 
portions were $11.2 \pm 0.8 \mathrm{~cm}$ in length, $4.3 \pm 0.3 \mathrm{~cm}$ in width, and $2.5 \pm 0.3 \mathrm{~cm}$ in height and they weighed $84.8 \pm 10.6 \mathrm{~g}$. Before each experiment, a batch of frozen loins was thawed at $5{ }^{\circ} \mathrm{C}$ for $24 \mathrm{~h}$.

\subsection{Experimental design and storage experiments}

Two sets of experiments were performed to evaluate the efficacy of hyperbaric cold storage in preserving hake loins. In the first group of experiments, we compared the effect of conventional and hyperbaric cold storage on the quality of the hake loins by using microbial, chemical, and physical quality indicators. In each storage experiment, 3 control loins ( $C$ samples) were analyzed at day 0 to assess the hake quality before storage. Moreover, 6 loins were individually packed in plastic bags and cold stored for 7 days: 3 of them conventionally, that is, at atmospheric pressure (C_CS samples) and the other 3 loins at high pressure (HP_CS samples). These storage experiments were performed in triplicate and, therefore, we employed a total of 27 hake loins (9 C_samples, 9 C_CS samples, and 9 HP_CS samples). After storage, quality indicators were analyzed in all the samples.

In the second group of experiments, a sensorial analysis was performed to detect possible differences between the hake loins before ( $C$ samples) and after hyperbaric cold storage (HP_CS samples). Before the storage experiments, the hake loins were divided into thirds to have portions, adequate in number and size, for the sensorial test. The portions obtained were packed in plastic bags and stored under pressure. Immediately after storage, HP_CS portions were compared with $\mathrm{C}$ portions. These storage experiments were performed in duplicate.

In all the experiments, $\mathrm{C}_{-} \mathrm{CS}$ samples were stored in a thermostatic chamber, at $5 \pm 2{ }^{\circ} \mathrm{C}$ and in the dark, for 7 days. HP_CS samples were kept at $50 \pm 2 \mathrm{MPa}$ and $5 \pm 2{ }^{\circ} \mathrm{C}$ for the same period. Storage experiments under pressure were carried out in a pilot-plant high-pressure storage system (model SV1, Institute of High Pressure Physics, Unipress Equipment Division, Poland). It was composed of two high-pressure stainless-steel vessels with independent pressure control, two control terminals, and a high-pressure pump. Both vessels had $100 \mathrm{~mm}$ internal diameter, $130 \mathrm{~mm}$ height, and a working volume of $1 \mathrm{~L}$ and they were located in individual thermostatic chambers. A mixture of propylene glycol and water ( $44 \% \mathrm{v} / \mathrm{v})$ was used as compressing fluid. Pressure and temperature were recorded every $30 \mathrm{~s}$ by a data acquisition system (MW100 Data Acquisition Unit, Yokogawa Electric Corporation, Tokyo, Japan). In all the experiments, the come-up time to reach the working pressure was less than $90 \mathrm{~s}$.

\subsection{Microbial indicators of the hake quality}

Samples were analyzed, before and immediately after storage, as described by Salgado, López-Caballero, Gómez-Guillén, Mauri, and Montero (2013). Briefly, $10 \mathrm{~g}$ of hake muscle was collected in a vertical laminar-flow cabinet (mod. AV 30/70 Telstar, Madrid, Spain) and introduced in a sterile plastic bag (Sterilin, Stone, Staffordshire, UK) with $90 \mathrm{~mL}$ of buffered 
0.1\% peptone water (Oxoid, Basingstoke, UK). After 1-minute processing in a Stomacher blender (model Colworth 400, Seward, London, UK), ten-fold serial dilutions were prepared in buffered peptone water and duplicates of the dilutions were plated on the appropriate medium, according to the procedures that follow.

Total aerobic mesophiles (TAM) were determined by the pour plate method on Plate Count Agar (PCA, Oxoid). Plates were incubated at $30^{\circ} \mathrm{C}$ for $72 \mathrm{~h}$ and the colonies formed were counted. Enterobacteriaceae (ENT) were quantified on double-layered plates of Violet Red Bile Glucose agar (VRBG, Oxoid) after incubation at $30^{\circ} \mathrm{C}$ for $48 \mathrm{~h}$. Plate counts were expressed as the decimal logarithm of colony-forming units (CFU) per gram of hake loin $\left(\log _{10} \mathrm{CFU} \cdot \mathrm{g}^{-1}\right)$. The detection limit was $1 \log _{10} \mathrm{CFU} \cdot \mathrm{g}^{-1}$ in both cases.

\subsection{Chemical indicators of the hake quality}

\subsection{1. $\mathrm{pH}$}

Fish flesh $(5 \mathrm{~g})$ was minced and homogenized in $50 \mathrm{~mL}$ of distilled water with a homogenizer (Ultra-Turrax T 25 basic, IKA Werke GmbH \& Co. KG, Germany). Then, the pH value was measured with a pH meter (pH-Burette 24 1S equipped with a pH 5021 electrode and a C.A.T. 5531 temperature sensor, Crison Instruments, Barcelona, Spain). Measurements were performed in each sample in duplicate and then averaged.

\subsubsection{Total volatile basic-nitrogen}

Total volatile basic-nitrogen (TVB-N) was measured according to the steam distillation method described by the European Commission Regulation 2074/2005 (European Community, 2005) with some slight modifications. In brief, $10 \mathrm{~g}$ of fish flesh was weighed and homogenized for 1 min with $90 \mathrm{~mL}$ of $6 \%$ perchloric acid to extract the volatile nitrogenous bases. After that, the blend was filtered through a Whatman no. 1 filter paper and brought to $100 \mathrm{~mL}$. Then, $50 \mathrm{~mL}$ of this extract was pipetted into the distillation tube, and after adding 5 drops of phenolphthalein and $9.5 \mathrm{~mL}$ of $20 \% \mathrm{NaOH}$, the steam distillation began immediately. The distillation outflow tube was submerged in a receiver with $100 \mathrm{~mL}$ of $3 \%$ boric acid and 3 drops of the indicator solution ( $0.01 \mathrm{~g}$ of methyl red $+0.02 \mathrm{~g}$ of bromothymol blue $+0.06 \mathrm{~g}$ of bromocresol green in $100 \mathrm{~mL}$ of ethanol (70\%)). After distilling $150 \mathrm{~mL}$ of the extract, distillation was considered completed. Finally, the volatile bases contained in both the sample and a blank solution (distilled as previously described, but $50 \mathrm{~mL}$ of perchloric acid was used instead of the extract) were determined by titration with $0.05 \mathrm{~N} \mathrm{HCl}$. The results were expressed as $\mathrm{mg}$ of TVB-N per $100 \mathrm{~g}$ of muscle according to:

$$
\text { TVB-N }\left(\frac{\mathrm{mg}}{100 \mathrm{~g} \mathrm{sample}}\right)=\frac{\left(\mathrm{V}_{1}-\mathrm{V}_{0}\right) \times 14.01 \times \mathrm{N} \times 2 \times 100}{\mathrm{M}}
$$


where $V_{1}$ and $V_{0}$ are the titration volume of $\mathrm{HCl}(\mathrm{mL})$ for the sample extract and the blank solution, respectively; $\mathrm{N}$ is the normality of the $\mathrm{HCl}$ solution; and $\mathrm{M}$ is the weight of the sample (g). TVB-N determinations were carried out in each sample in duplicate and then averaged.

\subsection{Physical indicators of the hake quality}

Several physical indicators were used to assess the quality of both raw and cooked hake loins. Thus, drip loss after storage, water content, water-holding capacity, toughness, and whiteness were evaluated in the raw samples, while cooking loss, toughness, and whiteness were determined in the cooked samples. Before cooking, samples were packed in aluminum foil, and then they were cooked in a saturated steam oven (Rational, Combi-Master CM 6, Croßküchentechnik $\mathrm{GmbH}$, Landsberg a. Lech, Germany) at $100^{\circ} \mathrm{C}$ for $4 \mathrm{~min}$.

\subsubsection{Drip loss after storage}

Drip loss after storage (DL) was determined by weighting the sample, superficially dried with a soft paper, before and after storage. DL was expressed as the percent of mass loss according to Eq. (2):

$$
\operatorname{DL}(\%)=\frac{\left(M_{b s}-M_{a s}\right)}{M_{b s}} \times 100
$$

where $M_{b s}$ and $M_{a s}$ are the masses ( $g$ ) of the loins before and after the storage period, respectively.

\subsubsection{Water content}

The water content (WC) was evaluated in the hake loins by determining the mass loss in about $5 \mathrm{~g}$ of chopped flesh after oven drying at $105^{\circ} \mathrm{C}$ until a constant weight was reached. WC was expressed according to equation (3):

$$
\text { WC }(\%)=\frac{\left(M_{b d}-M_{a d}\right)}{M_{b d}} \times 100
$$

where $M_{b d}$ and $M_{a d}$ are the masses ( $g$ ) of the chopped flesh before and after drying, respectively. WC measurements were performed in each sample in duplicate and then averaged.

\subsubsection{Water-holding capacity}

The water-holding capacity (WHC) of the hake loins was measured by using centrifugal force to remove the free and loosely bound water from the samples. For each determination, a portion of about $2 \mathrm{~cm} \times 2 \mathrm{~cm}$ was cut from the hake loin, weighed, and put into a centrifuge tube. The tube had a perforated disc, covered with 2 filter papers, and located approximately half way down the 
tube. The sample was placed on this perforated disc and centrifuged at $2200 \times g$ and $4{ }^{\circ} \mathrm{C}$ for 10 min (Sorvall Evolution RC centrifuge, model 728311, Thermo Electron Corporation,

216 Asheville, NC, USA). After centrifugation, the sample was superficially dried with a soft paper 217 and weighed again. Water-holding capacity (WHC) was expressed as the percent of water retained per $100 \mathrm{~g}$ of water present in the sample prior to centrifuging according to:

$$
\text { WHC }(\%)=\left(1-\frac{\left(M_{b c}-M_{a c}\right)}{M_{b c} \times W C}\right) \times 100
$$

221

222

223

224

225

226

227

228

230

231

232

233

234

235

236

237

238

239

240

241

242

243

244

245

246

247

where $\mathrm{M}_{\mathrm{bc}}$ and $\mathrm{M}_{\mathrm{ac}}$ are the masses ( $\mathrm{g}$ ) of the loin portions before and after centrifugation, respectively. WHC measurements were performed in each sample in duplicate and then averaged.

\subsubsection{Shear resistance}

The shear resistance of the raw and cooked samples was evaluated by a Kramer test. A Texture Analyser (TA-XTPlus, Stable Micro System Ltd., Surrey, UK), equipped with a 10-blade Kramer shear cell and controlled by the Texture Exponent 32 software (v. 6.1.5.0), was employed. Standardized portions $(1.5 \mathrm{~cm} \times 1 \mathrm{~cm} \times 3 \mathrm{~cm})$ were cut from each sample, parallel to the muscle fiber orientation, and any skin or fascia residue was removed. For the determinations, the hake portions were sheared $(2 \mathrm{~mm} / \mathrm{s}$ crosshead speed, $25 \mathrm{~kg}$ load cell), perpendicular to the muscle fiber orientation, and the shear resistance $(\mathrm{N} / \mathrm{g})$ was recorded. In each sample, determinations were performed in triplicate and then averaged.

\subsubsection{Whiteness}

The whiteness of the raw and cooked hake loins was characterized according to the $L^{*}, a^{*}$, and $b^{*}$ color parameters in the CIELab uniform color space defined by the Commission Internationale de l'Éclairage. To do so, a CM-3500d spectrophotometer managed with the color data software CM-S100w SpectraMagic ${ }^{\mathrm{TM}}$ (Konica Minolta, Tokyo, Japan) was employed. The illuminating and viewing configurations of the instrument complied with the $\mathrm{CIE}$ diffuse $/ 8^{\circ}$ geometry. The spectrophotometer operated in the reflectance specular included mode and the measuring aperture was $8 \mathrm{~mm}$ in diameter. Measurements were made with the D65 standard illuminant and a ten-degree observer angle. The instrument was calibrated with black and white standards before each series of analysis.

Whiteness was calculated, from $L^{*}, a^{\star}$, and $b^{\star}$ values, according to Eq. (5): 
In each sample, whiteness determinations were performed in triplicate and then averaged.

\subsubsection{Cooking loss}

Cooking loss $(\mathrm{CL})$ was determined by weighting the sample, superficially dried with a soft paper, before and after cooking. CL was expressed as the percentage of mass loss according to Eq. (6):

$$
C L(\%)=\frac{\left(M_{b c k}-M_{a c k}\right)}{M_{b c k}} \times 100
$$

where $M_{b c k}$ and $M_{a c k}$ are the masses ( $g$ ) of the loin portions before and after cooking, respectively. In each sample, CL determinations were performed in triplicate and then averaged.

260

\subsection{Sensorial analysis}

A triangle test was used to investigate possible sensory differences between the hake loins before ( $\mathrm{C}$ samples) and after 7 days of hyperbaric storage at $5{ }^{\circ} \mathrm{C}$ and $50 \mathrm{MPa}$ (HP_CS samples). The test was performed in two sessions with 30 semi-trained judges belonging to the staff of the Institute of Food Science, Technology, and Nutrition (ICTAN-CSIC).

Before the analysis, $45 \mathrm{C}$ and $45 \mathrm{HP}$ _CS hake portions were individually packed in aluminum foil and cooked 'en papillote' in an electric griddle for $9 \mathrm{~min}$. Three hake portions, from a similar part of the loin, were presented to the panelists to assure that possible differences were not due to loin portion effects. The samples, encoded by a three-digit random code, were served hot and at once on a white plate. Judges were informed that two samples were identical and one sample was different, and they were forced to identify the odd sample, even if they were not able to distinguish the difference between them. Judges were asked to record their answer in an evaluation worksheet, where they optionally could comment on the characteristics of the difference. No information about the aim of the study or about the samples was provided to the judges prior to the test.

\subsection{Statistical analysis}

278 Statistical analysis of the quality indicators was performed using IBM SPSS Statistics v. 22.0.0.1 279 for Windows (IBM Corp., Armonk, NY, USA). After a one-way analysis of variance (ANOVA), 280 significant differences among means were determined by a Tukey-b multiple range test in those 281 cases in which the prerequisite of homogeneity of variances was fulfilled. Otherwise, a Tamhane's post hoc test was employed. The significance level was set at 5\%. 
The results of the triangle tests were analyzed by comparing the sum of correct responses obtained in the tests with the minimum number of correct replies that are necessary for a significant result, according to the binomial distribution, given a particular number of panelists. When the number of correct responses was greater than or equal to this minimum value, the null hypothesis ('difference between samples does not exist') was rejected.

\section{RESULTS AND DISCUSSION}

\subsection{Effects of cold storage on the hake quality: Conventional versus hyperbaric cold storage}

Hake loins were stored at $5{ }^{\circ} \mathrm{C}$, either at atmospheric pressure or at $50 \mathrm{MPa}$, for 7 days. Before storage, the samples presented a pinky-white flesh and a wet and bright appearance. The skin had a metallic grey color and it was firmly attached to the flesh. After 7 days of storage, some modifications could be easily detected by the naked eye in all the samples. C_CS loins become sticky and off odors were detected in these samples. By contrast, HP_CS samples did not show perceptible changes to the touch and odor, but the color appeared a little more opaque.

\subsubsection{Microbial indicators of the hake quality}

After 7 days of storage at $5{ }^{\circ} \mathrm{C}$, the microbial load was significantly different $(p<0.05)$ in $\mathrm{C}$ CS and HP_CS samples (Table 1). TAM and ENT counts increased during storage by almost 3 and $5 \log _{10} \mathrm{CFU} / \mathrm{g}$, respectively, in the hake loins kept at atmospheric pressure. Thus, TAM counts in C_CS samples were over $7 \log _{10} \mathrm{CFU} / \mathrm{g}$, that is, the typical value reached in fish products at the time of sensory rejection (Olafsdóttir et al., 1997). By contrast, TAM and ENT growth was completely inhibited in the samples stored under pressure and, therefore, microbial counts did not significantly differ before and after hyperbaric storage (C and HP_CS samples).

These results agree well with those obtained by Ko and Hsu (2001) and Charm et al. (1977) who also reported no microbial growth in tilapia and cod fillets stored at 25-50 MPa for $12 \mathrm{~h}$ and 30 days, respectively. Thus, it is commonly accepted that pressure of several tens of MPa, although nonlethal for mesophilic microorganisms, can alter their structural organization and metabolic processes. Some cellular processes, such as motility, substrate transport, nutrient uptake, cell division, and DNA replication, translation, and transcription are adversely affected (Abe, 2007; Aoyama, Shigeta, Okazaki, Hagura, \& Suzuki, 2004; Bartlett, 2002) and, consequently, microbial growth is inhibited. However, it is important to note that, once high pressure is released, microorganisms can recover from these adverse effects and proliferate. Thus, several authors in the literature have shown that, after hyperbaric storage at 50-100 MPa for up to 15 days, microorganisms can recover their cell-proliferating ability in different foods 
(Bermejo-Prada et al., 2016; Fidalgo et al., 2014; Freitas et al., 2016; Moreira et al., 2015a). Therefore, if the hake loins are not going to be immediately consumed or processed after hyperbaric cold storage at $50 \mathrm{MPa}$, they should be subsequently cold stored at atmospheric pressure until use to prevent, to a certain extent, that microorganisms resume their metabolic activity.

\subsubsection{Chemical indicators of the hake quality}

After 7 days of storage at $5^{\circ} \mathrm{C}$, no variations were detected in the $\mathrm{pH}$ values of both $\mathrm{C} \_\mathrm{CS}$ and HP_CS samples compared with $\mathrm{C}$ loins (Table 1). Other authors have reported that $\mathrm{pH}$ values in fish increase during storage (Angsupanich \& Ledward, 1998; Baixas-Nogueras, Bover-Cid, Veciana-Nogués, Nunes, \& Vidal-Carou, 2003; Pastoriza, Sampedro, Herrera, \& Cabo, 1998; Simeonidou, Govaris, \& Vareltzis, 1997), mainly due to the basic compounds produced when the fish muscle is degraded by enzymatic reactions and microbial activity (Huss, 1995). Thus, Baixas-Nogueras et al. (2003) observed pH increases of $0.06,0.22$, and 0.44 in hake fillets after 8,10 , and 14 days of storage in ice, respectively. In our study, mean pH increases after 7 days of storage were 0.05 and 0.02 in C_CS and HP_CS samples, respectively, but this storage time seems to be too short to observe significant differences among the samples.

The total volatile basic-nitrogen content in the hake loins at day 0 was $11.27 \pm 0.67 \mathrm{mg} / 100 \mathrm{~g}$ (Table 1). After 7 days of storage at $5{ }^{\circ} \mathrm{C}$, TVB-N values were triplicated in the samples stored at atmospheric pressure. Thus, TVB-N content exceeded the limit value established by the Commission Regulation (EC) No. 2074/2005 (European Community, 2005); namely, $35 \mathrm{mg} / 100 \mathrm{~g}$ for Merlucciidae species. By contrast, TVB-N content in the hake loins stored at $50 \mathrm{MPa}$ remained constant.

TVB-N quantifies a wide range of basic volatile compounds, such as ammonia, methylamine, dimethylamine, and trimethylamine, among others. These compounds are produced through different metabolic paths during fish degradation by both autolytic processes and microbial activity. Therefore, the TVB- $N$ values shown in Table 1 are consistent with the microbial counts reported in section 3.1.1. Thus, during storage, TAM and ENT counts increased significantly in C_CS samples and, consequently, also the TVB-N content. By contrast, no changes were observed in the microbial counts or the TVB-N values of HP_CS samples. This result is particularly interesting because it not only confirms that hyperbaric storage inhibits microbial growth, but it also shows that other autolytic processes are not pressure enhanced.

\subsubsection{Physical indicators of the hake quality}

Cold storage for 7 days, either at atmospheric pressure or at $50 \mathrm{MPa}$, produced significant changes in some physical indicators of the quality of the raw samples. Thus, drip losses, close 
to $5 \%$, were detected in both C_CS and HP_CS samples that significantly reduced $(p<0.05)$ the water content of the hake loins (Table 1 ). Moreover, the water-holding capacity was larger in C_CS and HP_CS samples, probably because part of the free water in these samples had been previously released as drip loss and the water still present was more strongly retained by the tissue. Furthermore, hyperbaric cold storage, unlike conventional refrigeration, increased the shear resistance and whiteness of the hake loins significantly.

361 It is well-known that, during cold storage, myofibrillar proteins, the main responsible for the physical characteristics of myosystems, can be modified by enzymatic and non-enzymatic reactions (Chéret et al., 2005). As a result, significant drip losses, dehydration, and apparent WHC, texture, and color changes are frequently reported in fish after conventional cold storage (Cao et al., 2016; Chéret et al., 2005; Hurtado, Montero, \& Borderias, 2000; Olsson, Ofstad, Lødemel, \& Olsen, 2003; Pastoriza et al., 1998).

When cold storage is performed under pressure, additional pressure-induced effects must be considered. It is commonly accepted that pressure can provoke changes in hydrogen, hydrophobic, and disulfide bonds which are responsible for maintaining the tertiary structure of proteins (Mozhaev, Heremans, Frank, Masson, \& Balny, 1996). These conformational changes can produce protein denaturation, and depending on the pressure level and the holding time, protein can simply unfold, aggregate, or even precipitate and gel (Balny \& Masson, 1993; Hsu \& $\mathrm{Ko}, 2001)$. In this sense, Hsu and $\mathrm{Ko}$ (2001) showed that, at $50 \mathrm{MPa} / 0^{\circ} \mathrm{C}$, tilapia myosin unfolded due to intramolecular interactions that reduced the molecular volume, but it did not aggregate or gel. At this pressure level, hydrophobic interactions increased, probably due to the emergence of amino acid residues to the molecular surface. Moreover, the total sulfhydryl content was reduced because intramolecular disulfide bonds were formed (Hsu, Hwang, Yu, \& Jao, 2007; Ko et al., 2003). All these changes did not substantially affect the gel forming capacity of tilapia meat and the Ca-ATPase activity and; thus, the processing quality of tilapia fillets stored at $50 \mathrm{MPa}$ and $25^{\circ} \mathrm{C}$ for $12 \mathrm{~h}$ was well preserved (Ko et al., 2006). However, in this paper, we found that this pressure level, applied for 7 days, significantly increased the shear resistance and whiteness of the hake loins.

Significant changes in the shear resistance and hardness of high-pressure treated fish muscle have been previously reported in the literature, although there are some differences from one fish species to another (Angsupanich \& Ledward, 1998; Ashie, Simpson, \& Ramaswamy, 1997; Gómez-Estaca, López-Caballero, Gómez-Guillén, López de Lacey, \& Montero, 2009). In general, the effect of pressure processing depends on the pressure level applied and, thus, muscle hardness usually increases up to a maximum pressure level after which hardness decreases as a result of the muscle disintegration. In hake, Vidacek, de las Heras, Solas, Rodriguez Mahillo, and Tejada (2009) reported that the shear resistance increased by twice after cold pressurizing the product at $200 \mathrm{MPa}$ for only 1 minute. In this paper, after 7 days at 50 $\mathrm{MPa}$, we observed a much lower increase; namely, the shear resistance increased by $44 \%$. 
Previous papers in the literature also reported pressure effects on the color of fish flesh, both in species with red-orange flesh (Erkan, Üretener, \& Alpas, 2010; Matser et al., 2000) and in those with white flesh (Chéret et al., 2005; Hurtado et al., 2000; Matser et al., 2000; Vidacek et al., 2009). The mechanism involved in this color change is still unclear, but pressure effects on protein denaturation and the physical structure of the muscle could be implied. Moreover, pressure effects on heme compounds and on the amount of unbound water, that influences light scattering, should not be discarded (Chéret et al., 2005; Matser et al., 2000; Montero \& GómezGuillén, 2004). In general, pressure processing makes fish to acquire a cooked, opaque appearance and the higher the pressure and the longer the pressure holding time, the more apparent these changes (Chéret et al., 2005; Chevalier et al., 2001; Matser et al., 2000; Vidacek et al., 2009). Thus, for example, according to the chromatic parameters ( $L^{*}, a^{*}$, and $\left.b^{*}\right)$ recorded by Chevalier et al. (2001), the whiteness of turbot fillets increased by $10.4 \%$ when they were pressurized at $100 \mathrm{MPa} / 4^{\circ} \mathrm{C}$ for $30 \mathrm{~min}$, but by $39.2 \%$ after the same holding time at 200 $\mathrm{MPa}$. In hake, Hurtado et al. (2000) observed a whiteness increase of $36.4 \%$ after 3 pressure cycles $(5+5+5 \mathrm{~min})$ at $200 \mathrm{MPa} / 7^{\circ} \mathrm{C}$, while Vidacek et al. (2009) detected whiteness increases of only $0.6-2.6 \%$ after short pressure treatments (1-5 min) at $200 \mathrm{MPa}$. In this paper, the whiteness of hake loins increased by only $8.9 \%$ after 7 days at $50 \mathrm{MPa}$, probably because this pressure level is too low to substantially affect the mechanisms implied in pressure induced color changes.

The effect of cooking was also evaluated in some physical indicators of the hake quality. Heating causes denaturation and aggregation of proteins and this produces the shrinkage and disintegration of myofibrils and the subsequent release of water, soluble proteins, and fats from the tissue (Kong, Tang, Rasco, \& Crapo, 2007; Ofstad, Kidman, Myklebust, \& Hermansson, 1993; Skipnes, Johnsen, Skåra, Sivertsvik, \& Lekang, 2011). Thus, after cooking, weight losses were observed in all the hake loins (Table 1). Moreover, the shear resistance and the whiteness increased in all the samples.

419 Table 1 reveals that the cooking losses in the hake loins stored under pressure were 420 significantly lower than in all the other samples and this should contribute to minimize the effect of the drip losses observed after storage. However, the texture differences detected among the raw hake loins remained after cooking and, thus, the shear resistance was significantly larger in the samples stored under pressure. By contrast, the whiteness differences disappeared after cooking and, therefore, the pressure-induced changes in the color of the hake loins should not be appreciated as a drawback when consuming the product.

427 3.2. Effect of hyperbaric storage on the sensorial quality of cooked hake loins: 428 Differences before and after storage

429 After cooking the hake loins, a triangle difference test was performed to check if the panelists 430 could differentiate between the control samples and those stored at $5^{\circ} \mathrm{C}$ and $50 \mathrm{MPa}$ for Innovative Food Science and Emerging Technologies 41(2017) 19-25. DOI: 10.1016/j.ifset.2017.01.003 

because the samples, after 7 days of storage, were not acceptable for consumption.

Among the 30 judges involved in the test, only 16 of them could correctly identify the odd sample. From these results, Table 2 concludes that C and HP_CS samples are significantly different if an a-risk (risk of concluding that a difference exists when it does not) of $5 \%$ is assumed. For lower a-risks, no significant differences were detected. Therefore, the effects of hyperbaric cold storage on the sensory properties of the hake loins, even though perceptible, seem not to be large because only moderate evidence of apparent differences between the samples could be found (Meilgaard, Civille, \& Carr, 2007).

The panelists who correctly identified the samples mainly referred differences in the texture of the samples. Thus, 9 judges reported a harder texture in HP_CS samples than in C loins. These comments agree with the results of the instrumental measurements that showed significantly lower $(p<0.05)$ shear resistance in $C$ samples.

\section{CONCLUSIONS}

The results obtained in this paper clearly show that hyperbaric storage, at $50 \mathrm{MPa}$ and $5{ }^{\circ} \mathrm{C}$, is a method more effective than conventional refrigeration for limiting hake degradation. Thus, conventional refrigeration failed to extend the shelf-life of the samples for 7 days, both if $6 \log _{10}$ CFU/g or if $35 \mathrm{mg} / 100 \mathrm{~g}$ are considered as TAM and TVB-N limits of acceptability. By contrast, hyperbaric cold storage allowed to maintain microbial counts and TVB-N content unaltered for, at least, 7 days. Storage under pressure increased the shear resistance and whiteness of the raw hake loins but, after cooking, sensorial differences between C and HP_CS samples, even though perceptible as an increased hardness, were only moderate.

Our results show that hyperbaric cold storage could be an interesting technology for fish preservation. The increased cost resulting from hyperbaric storage should be overcome by an extended shelf-life of a high-quality product. Hyperbaric cold storage might allow fish to be delivered to long-distance markets, would increase their commercial value, and reduce economic losses. All these advantages should be considered when calculating the real benefit of this novel technology. Moreover, it is important to note that the main cost of hyperbaric storage corresponds to the equipment acquisition. The innovations performed during the last years in equipment design have made possible a decreasing trend in the cost of high-pressure equipment from 1996 to now. More cost reductions must be expected if the demand follows its climbing tendency and new high-pressure applications, such as hyperbaric storage, are implemented in the food industry. 
studies are needed to assess the effect of pressure on different mechanisms, other than microbial activity, implied in fish degradation, such as enzymatic activity, lipid oxidation and so on, both during and after hyperbaric storage.

\section{Acknowledgments}

This work was supported by the State Plan for Scientific and Technical Research and Innovation 2013-2016 of the Spanish Ministry of Economy and Competitiveness (MINECO) through the CONSOLIDER-Network MAT2015-71070-REDC and the project AGL2014-52825. The authors thank Laura Barrios, head of the Statistical and Operational Research Service of CSIC (Spain), for her advice in the statistical analysis of the data; María José Jiménez, head of the Sensory Analysis Unit of ICTAN-CSIC, for her help in the sensorial analysis of the samples; and Ignacio Rodríguez and Ignacio Escudero, both technicians at ICTAN-CSIC, for their assistance in the lab work. The authors also thank Marie Caroline Legland, Master student, for her help in obtaining and processing part of the data.

\section{REFERENCES}

Abe, F. (2007). Exploration of the effects of high hydrostatic pressure on microbial growth, physiology and survival: Perspectives from piezophysiology. Bioscience, Biotechnology, and Biochemistry, 71(10), 2347-2357.

Angsupanich, K., \& Ledward, D. A. (1998). High pressure treatment effects on cod (Gadus morhua) muscle. Food Chemistry, 63(1), 39-50.

Aoyama, Y., Shigeta, Y., Okazaki, T., Hagura, Y., \& Suzuki, K. (2004). Growth inhibition of microorganisms by hydrostatic pressure. Food Science and Technology Research, 10(3), 268-272.

Ashie, I. N., Simpson, B. K., \& Ramaswamy, H. S. (1997). Changes in texture and microstructure of pressure-treated fish muscle tissue during chilled storage. Journal of Muscle Foods, 8(1), 13-32.

Ashie, I. N., Smith, J. P., \& Simpson, B. K. (1996). Spoilage and shelf-life extension of fresh fish and shellfish. Critical Reviews in Food Science and Nutrition, 36(1-2), 87-121.

Baixas-Nogueras, S., Bover-Cid, S., Veciana-Nogués, T., Nunes, M. L., \& Vidal-Carou, M. C. (2003). Development of a quality index method to evaluate freshness in Mediterranean hake (Merluccius merluccius). Journal of Food Science, 68(3), 10671071.

Balny, C., \& Masson, P. (1993). Effects of high pressure on proteins. Food Reviews International, 9(4), 611-628.

Bartlett, D. H. (2002). Pressure effects on in vivo microbial processes. Biochimica et Biophysica Acta (BBA) - Protein Structure and Molecular Enzymology, 1595(1-2), 367-381.

Bermejo-Prada, A., Colmant, A., Otero, L., \& Guignon, B. (2017). Industrial viability of the hyperbaric method to store perishable foods at room temperature. Journal of Food Engineering, 193, 76-85.

Bermejo-Prada, A., López-Caballero, M. E., \& Otero, L. (2016). Hyperbaric storage at room temperature: Effect of pressure level and storage time on the natural microbiota of strawberry juice. Innovative Food Science \& Emerging Technologies, 33, 154-161.

Cao, L., Rasco, B. A., Tang, J., Liu, L., Lai, K., Fan, Y., \& Huang, Y. (2016). Effects of freshness on the cook loss and shrinkage of grass carp (Ctenopharyngodon idellus) fillets following pasteurization. International Journal of Food Properties, 19(10), 2297-2306. 
Charm, S. E., Longmaid, H. E., \& Carver, J. (1977). Simple system for extending refrigerated, nonfrozen preservation of biological-material using pressure. Cryobiology, 14(5), 625636.

Chéret, R., Chapleau, N., Delbarre-Ladrat, C., Verrez-Bagnis, V., \& De Lamballerie, M. (2005). Effects of high pressure on texture and microstructure of sea bass (Dicentrarchus labrax L.) fillets. Journal of Food Science, 70(8), E477-E483.

Chevalier, D., Le Bail, A., \& Ghoul, M. (2001). Effects of high pressure treatment (100-200 MPa) at low temperature on turbot (Scophthalmus maximus) muscle. Food Research International, 34(5), 425-429.

Erkan, N., Üretener, G., \& Alpas, H. (2010). Effect of high pressure (HP) on the quality and shelf life of red mullet (Mullus surmelutus). Innovative Food Science \& Emerging Technologies, 11(2), 259-264.

European Community. (2005). EC Commission Regulation No 2074/2005 of 5 December 2005. Official Journal of the European Union L, 338, 27:59.

Fernandes, P. R., Moreira, S., Fidalgo, L., Santos, M., Queirós, R., Delgadillo, I., \& Saraiva, J. (2014). Food preservation under pressure (hyperbaric storage) as a possible improvement/alternative to refrigeration. Food Engineering Reviews, 1-10.

Fidalgo, L., Santos, M., Queirós, R., Inácio, R., Mota, M., Lopes, R., Gonçalves, M., Neto, R., \& Saraiva, J. (2014). Hyperbaric storage at and above room temperature of a highly perishable food. Food and Bioprocess Technology, 7(7), 2028-2037.

Freitas, P., Pereira, S. A., Santos, M. D., Alves, S. P., Bessa, R. J. B., Delgadillo, I., \& Saraiva, J. A. (2016). Performance of raw bovine meat preservation by hyperbaric storage (quasi energetically costless) compared to refrigeration. Meat Science, 121, 64-72.

Gómez-Estaca, J., López-Caballero, M. E., Gómez-Guillén, M. C., López de Lacey, A., \& Montero, P. (2009). High pressure technology as a tool to obtain high quality carpaccio and carpaccio-like products from fish. Innovative Food Science \& Emerging Technologies, 10(2), 148-154.

Hsu, K. C., Hwang, J. S., Yu, C. C., \& Jao, C. L. (2007). Changes in conformation and in sulfhydryl groups of actomyosin of tilapia (Orechromis niloticus) on hydrostatic pressure treatment. Food Chemistry, 103(2), 560-564.

Hsu, K. C., \& Ko, W. C. (2001). Effect of hydrostatic pressure on aggregation and viscoelastic properties of tilapia (Orechromis niloticus) myosin. Journal of Food Science, 66(8), 1158-1162.

Hurtado, J. L., Montero, P., \& Borderias, A. J. (2000). Extension of shelf life of chilled hake (Merluccius capensis) by high pressure. Food Science and Technology International, 6(3), 243-249.

Huss, H. H. (1995). Quality and quality changes in fresh fish. In. Rome: Food and Agriculture Organization of the United Nations

Ko, W. C., \& Hsu, K. C. (2001). Changes in K value and microorganisms of tilapia fillet during storage at high-pressure, normal temperature. Journal of Food Protection, 64(1), 9498.

Ko, W. C., \& Hsu, K. C. (2002). Effect of high-pressure storage on the processing quality of tilapia meat. In H. Rikimaru (Ed.), Progress in Biotechnology (Vol. 19, pp. 411-416): Elsevier.

Ko, W. C., Jao, C. L., \& Hsu, K. C. (2003). Effect of hydrostatic pressure on molecular conformation of tilapia (Orechromis niloticus) myosin. Journal of Food Science, 68(4), 1192-1195.

Ko, W. C., Jao, C. L., Hwang, J. S., \& Hsu, K. C. (2006). Effect of high-pressure treatment on processing quality of tilapia meat fillets. Journal of Food Engineering, 77(4), 1007-1011.

Kong, F., Tang, J., Rasco, B., \& Crapo, C. (2007). Kinetics of salmon quality changes during thermal processing. Journal of Food Engineering, 83(4), 510-520. 
Matser, A. M., Stegeman, D., Kals, J., \& Bartels, P. V. (2000). Effects of high pressure on colour and texture of fish. High Pressure Research, 19(1-6), 109-115.

Meilgaard, M., Civille, G. V., \& Carr, B. T. (2007). Overall difference tests: Does a sensory difference exist between samples? In Sensory Evaluation Techniques (Fourth Edition ed., pp. 63:104). Boca Raton, FL: CRC Press. Taylor \& Francis Group.

Montero, P., \& Gómez-Guillén, M. C. (2004). High-pressure applications on myosystems. In G. V. Barbosa-Canovas, M. S. Tapia \& M. P. Cano (Eds.), Novel food processing technologies (pp. 311-342). Boca Raton, FL, USA: CRC Press. Taylor \& Francis Group.

Moreira, S. A., Duarte, R. V., Fernandes, P. A. R., Alves, S. P., Bessa, R. J., Delgadillo, I., \& Saraiva, J. A. (2015a). Hyperbaric storage preservation at room temperature using an industrial-scale equipment: Case of two commercial ready-to-eat pre-cooked foods. Innovative Food Science \& Emerging Technologies, 32, 29-36.

Moreira, S. A., Fernandes, P. A., Duarte, R., Santos, D. I., Fidalgo, L. G., Santos, M. D., Queiros, R. P., Delgadillo, I., \& Saraiva, J. A. (2015b). A first study comparing preservation of a ready-to-eat soup under pressure (hyperbaric storage) at $25{ }^{\circ} \mathrm{C}$ and $30{ }^{\circ} \mathrm{C}$ with refrigeration. Food Sci Nutr, 3(6), 467-474.

Mozhaev, V. V., Heremans, K., Frank, J., Masson, P., \& Balny, C. (1996). High pressure effects on protein structure and function. Proteins: Structure, Function, and Bioinformatics, 24(1), 81-91.

Ofstad, R., Kidman, S., Myklebust, R., \& Hermansson, A. M. (1993). Liquid holding capacity and structural changes during heating of fish muscle: cod (Gadus morhua L.) and salmon (Salmo salar). Food structure., 12(2), 163-174.

Olafsdóttir, G., Martinsdóttir, E., Oehlenschläger, J., Dalgaard, P., Jensen, B., Undeland, I., Mackie, I. M., Henehan, G., Nielsen, J., \& Nilsen, H. (1997). Methods to evaluate fish freshness in research and industry. Trends in Food Science \& Technology, 8(8), 258265.

Olsson, G. B., Ofstad, R., Lødemel, J. B., \& Olsen, R. L. (2003). Changes in water-holding capacity of halibut muscle during cold storage. LWT - Food Science and Technology, 36(8), 771-778.

Pastoriza, L., Sampedro, G., Herrera, J. J., \& Cabo, M. L. (1998). Influence of sodium chloride and modified atmosphere packaging on microbiological, chemical and sensorial properties in ice storage of slices of hake (Merluccius merluccius). Food Chemistry, 61(1-2), 23-28.

Pinto, C., Moreira, S. A., Fidalgo, L. G., Santos, M. D., Delgadillo, I., \& Saraiva, J. A. (2016). Shelflife extension of watermelon juice preserved by hyperbaric storage at room temperature compared to refrigeration. LWT - Food Science and Technology, 72, 7880.

Rahman, M. S. (1999). Postharvest handling of foods of animal origin. In M. S. Rahman (Ed.), Handbook of food preservation (pp. 47-73). New York: Marcel Dekker.

Salgado, P. R., López-Caballero, M. E., Gómez-Guillén, M. C., Mauri, A. N., \& Montero, M. P. (2013). Sunflower protein films incorporated with clove essential oil have potential application for the preservation of fish patties. Food Hydrocolloids, 33(1), 74-84.

Sampels, S. (2015). The effects of storage and preservation technologies on the quality of fish products: A review. Journal of Food Processing and Preservation, 39(6), 1206-1215.

Segovia-Bravo, K. A., Guignon, B., Bermejo-Prada, A., Sanz, P. D., \& Otero, L. (2012). Hyperbaric storage at room temperature for food preservation: A study in strawberry juice. Innovative Food Science and Emerging Technologies, 15(0), 14-22.

Simeonidou, S., Govaris, A., \& Vareltzis, K. (1997). Effect of frozen storage on the quality of whole fish and fillets of horse mackerel (Trachurus trachurus) and mediterranean hake (Merluccius mediterraneus). Zeitschrift für Lebensmitteluntersuchung und -Forschung A, 204(6), 405-410. 
Skipnes, D., Johnsen, S. O., Skåra, T., Sivertsvik, M., \& Lekang, O. (2011). Optimization of heat processing of farmed Atlantic cod (Gadus morhua) muscle with respect to cook loss, water holding capacity, color, and texture. Journal of Aquatic Food Product Technology, 20(3), 331-340.

Vidacek, S., de las Heras, C., Solas, M. T., Rodriguez Mahillo, A. I., \& Tejada, M. (2009). Effect of high hydrostatic pressure on mortality and allergenicity of Anisakis simplex L3 and on muscle properties of infested hake. Journal of the Science of Food and Agriculture, 89(13), 2228-2235.

Wilhelm, K. A. (1982). Extended fresh storage of fishery products with modified atmospheres: A survey. Marine Fisheries Review, 44(2), 17-20.

TABLE 1 Microbial, chemical, and physical indicators of the hake quality before ( $C$ samples, $n=9$ ) and after 7 days of either conventional (C_CS samples: $0.1 \mathrm{MPa} / 5 \mathrm{C}, \mathrm{n}=9)$ or hyperbaric $\left(\mathrm{HP} \_\mathrm{CS}\right.$ samples: $\left.50 \mathrm{MPa} / 5^{\circ} \mathrm{C}, \mathrm{n}=9\right)$ cold storage.

\begin{tabular}{|c|c|c|c|}
\hline \multirow[b]{2}{*}{ Sample } & \multirow{2}{*}{$\begin{array}{c}\text { Day } 0 \\
\text { C } \\
\end{array}$} & \multicolumn{2}{|c|}{ Day 7} \\
\hline & & C_Cs & HP_CS \\
\hline \multicolumn{4}{|l|}{ Microbial indicators of the hake quality } \\
\hline Total aerobic mesophiles $\left(\log _{10} \mathrm{CFU} / \mathrm{g}\right)$ & $4.76 \pm 0.43 \mathrm{a}$ & $7.70 \pm 0.21 b$ & $4.51 \pm 0.34 \mathrm{a}$ \\
\hline Enterobacteriaceae $\left(\log _{10} \mathrm{CFU} / \mathrm{g}\right)$ & $1.87 \pm 0.34 \mathrm{a}$ & $6.48 \pm 0.24 b$ & $<1 \quad a$ \\
\hline \multicolumn{4}{|l|}{ Chemical indicators of the hake quality } \\
\hline $\mathrm{pH}$ & $6.89 \pm 0.05 a$ & $7.03 \pm 0.08 \mathrm{a}$ & $6.91 \pm 0.04 \mathrm{a}$ \\
\hline Total volatile basic nitrogen $(\mathrm{mg} / 100 \mathrm{~g})$ & $11.08 \pm 1.02 \mathrm{a}$ & $38.65 \pm 4.52 b$ & $9.96 \pm 1.12 \mathrm{a}$ \\
\hline \multicolumn{4}{|l|}{ Physical indicators of the hake quality } \\
\hline \multicolumn{4}{|l|}{ Before cooking } \\
\hline Drip loss (\%) & - & $4.94 \pm 0.79 \mathrm{a}$ & $5.24 \pm 0.54 \mathrm{a}$ \\
\hline Water content (\%) & $81.43 \pm 0.40 \mathrm{a}$ & $79.46 \pm 0.36 b$ & $80.23 \pm 0.44 b$ \\
\hline Water holding capacity (\%) & $67.45 \pm 0.79 a$ & $77.79 \pm 1.00 \mathrm{~b}$ & $78.70 \pm 0.98 b$ \\
\hline Shear resistance $(\mathrm{N} / \mathrm{g})$ & $4.11 \pm 0.44 \mathrm{a}$ & $3.80 \pm 0.28 a$ & $5.92 \pm 0.48 b$ \\
\hline Whiteness & $53.11 \pm 0.79 a$ & $55.23 \pm 0.51 \mathrm{a}$ & $57.83 \pm 0.86 b$ \\
\hline \multicolumn{4}{|l|}{ After cooking } \\
\hline Cooking loss (\%) & $13.40 \pm 1.48 \mathrm{a}$ & $11.97 \pm 1.73 \mathrm{a}$ & $5.75 \pm 0.39 b$ \\
\hline Shear resistance $(\mathrm{N} / \mathrm{g})$ & $6.42 \pm 0.51 \mathrm{a}$ & $5.58 \pm 0.34 a$ & $8.71 \pm 0.84 b$ \\
\hline Whiteness & $65.93 \pm 0.94 a$ & $67.08 \pm 0.35 a$ & $66.02 \pm 0.65 a$ \\
\hline
\end{tabular}


TABLE 2 Triangle test to detect any possible difference between hake loins before (C samples) and after 7 days of storage at $5^{\circ} \mathrm{C}$ and $50 \mathrm{MPa}$ (HP_CS samples). Sensorial analysis was performed after cooking the samples. MN_CR: Minimum number of correct responses required for significance at different significance

646

647

\begin{tabular}{lcccc}
\hline Triangle test & Total responses & Correct responses & MN_CR & $\begin{array}{c}\text { Evidence that a } \\
\text { difference is } \\
\text { apparent }^{1}\end{array}$ \\
\hline C vs. HP_CS & 30 & 16 & 16 for $\alpha<0.05$ & Moderate \\
& & & 19 for $\alpha<0.001$ & Very strong \\
648 & 1Mengaard et al.(200) & & \\
650 & & & \\
651 & & & \\
650 & & & \\
\end{tabular}

